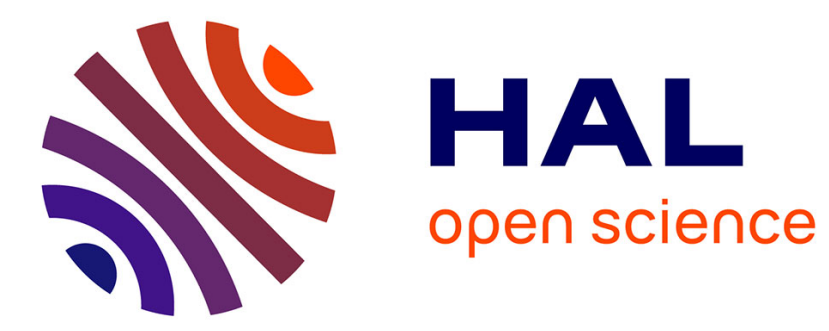

\title{
On the Modal Meanings of the Subjunctive in Hindi \\ Ghanshyam Sharma
}

\section{To cite this version:}

Ghanshyam Sharma. On the Modal Meanings of the Subjunctive in Hindi. Rajendra Singh. The Yearbook of South Asian Languages and Linguistics, Mouton de Gruyter 2002, 3-11-017580-0; ISSN 0971-9539. hal-01386177

\section{HAL Id: hal-01386177 \\ https://hal-inalco.archives-ouvertes.fr/hal-01386177}

Submitted on 23 Oct 2016

HAL is a multi-disciplinary open access archive for the deposit and dissemination of scientific research documents, whether they are published or not. The documents may come from teaching and research institutions in France or abroad, or from public or private research centers.
L'archive ouverte pluridisciplinaire HAL, est destinée au dépôt et à la diffusion de documents scientifiques de niveau recherche, publiés ou non, émanant des établissements d'enseignement et de recherche français ou étrangers, des laboratoires publics ou privés. 


\title{
On the Modal Meanings of the Subjunctive in Hindi
}

\author{
-Ghanshyam Sharma \\ University of Venice
}

The paper deals with the modal meanings of the Hindi subjunctive in the light of an overall picture of the Hindi verbal predicate. It argues that modal meanings are the speaker's meaning which may or may not be grammaticalized, and therefore it is difficult to provide a full picture of modal meanings of the subjunctive in syntactic terms only. Furthermore, the paper establishes that the Hindi subjunctive is employed by the speaker to express both epistemic and deontic possibilities rather than epistemic and deontic necessities.

\section{-1. INTRODUCTION}

In the present paper we make an attempt to analyze various kinds of modal meanings expressed through the subjunctive verbal predicates in Hindi. ${ }^{1}$ In doing so, we will be concerned mainly with the epistemic and deontic aspects of the subjunctive forms of the Hindi verb and will not investigate in any detail their possible syntactic characterizations. In order to establish modal meanings of the subjunctive verbal predicate, we shall try to see it in the light of an overall picture of other verbal predicates which express either epistemic necessity and possibility, or deontic necessity and possibility. The paper seeks to establish that the modal meanings in natural languages are expressed at different levels of the utterance and therefore can be studied from different perspectives, i.e. from the point of view of the speaker, from the point of view of the person referred to, or, in the case of reported speech, from the point of view of the speaker referred to in the utterance. The present study, however, concerns modality expressed at the level of sentence only and does not take into consideration modality which is related to the persons mentioned or referred to in the utterance. In accordance with the functions of the subjunctive in many languages of the world, the Hindi subjunctive is used by the speaker to express meanings relating to modal possibilities rather than to express modal necessities which are generally conveyed by the Hindi indicatives. Furthermore, the paper claims that in Hindi this dual distinction between possibility and necessity can be found at the level of deontic modality as well. A speaker can, for example, ask his addressee to carry out an action $x$ either necessarily or possibly. In the former case, the speaker issues a command through an imperative, asking the addressee to carry out the task necessarily, whereas, in the latter, the speaker gives the addressee the possibility of non-compliance with the command. Such meanings are articulated by polite commands made with the subjunctive. 


\section{-2. WHAT DO WE MEAN BY MODALITY?}

The term modality has been used in different senses in linguistics to indicate those different kinds of additional semantic elements which are attached by the speaker to a sentence or utterance by different means in different languages of the world. At times, the term is used to indicate any grammatical elements which do not fit into any known categories, even to indicate sentence types such as Interrogative ${ }^{2}$ etc., whereas sometimes it is used in a very technical and limited sense, taking into consideration grammatical categories which express epistemic and deontic modalities only. The term modality is used differently also with respect to its scope; at times it is related to an agent referred to by the hearer and at times it is considered in relation to the sentence as a whole. Keeping in mind this diversity of uses of the term 'modality', Van der Auwera and Plungian (1998) presents a classification of different types of modalities according to which the necessity and possibility elements can be found both at sentence level (participant-external level) as well as at the level of the participants (participant-internal level) of the discourse. ${ }^{3}$ It is this diversity of the meaning of the term modality that is responsible for its having been neglected in linguistic research for a long time. Though the origin of modality-based research can be traced back to grammarians such as Jespersen ${ }^{4}$ (1924) and logicians like von Wright ${ }^{5}$ (1951) and Rescher (1968), it is Lyons (1977) and Palmer (1986), however, who constitute a systematic beginning of research on modality, especially in linguistics. In the present study, by modality we mean those semantic or grammatical elements of a sentence or utterance - similar to aspect, tense etc. - which indicate the way in which the speaker is committed to the truth of the proposition contained in a sentence (or utterance). The tense is thought to indicate the time reference of the action in relation to the time of utterance and the aspect indicates the internal temporal constituency of the action ${ }^{6}$; modality is concerned primarily with the way in which the speaker commits himself to the addressee about the truthfulness of the action(s) or any state of affairs reported in the sentence. In other words, at times the speaker is in a secure position of asserting the states of affairs described in the sentence since he knows them, at other times, he cannot with certainty share with the addressee the information about the action(s) or state(s) of affairs contained in the sentence. In such cases he merely informs the addressee of the possibility that they may or might take place or might have been taking place. Furthermore, the speaker, at times, does not know about the states of affairs, but rather believes that they must necessarily be taking place or will certainly take place. The veridicality of the proposition, therefore, is the sole factor in recognizing the modality of the sentence. We will keep to this view throughout the present paper and will be interested in analyzing sentence level modality only, leaving the topic of participant-internal modality for further studies.

\section{- 2.1 DIFFERENT LAYERS OF MODALITY IN UTTERANCES}

As stated earlier, modality should be studied at least at three levels: at the level of the speaker, at the level of subject of the utterance and at the level of the person mentioned. Theoretically, these levels could be even more than three, but it will suffice to say that it is not sufficient to provide syntactic or semantic explanations for the modality operators just at the level of sentence. Sentences not always show all the layers of the modality at their surface level and hence no theory could be provided to account for all the semantic elements of modality. We propose to make a distinction between these different layers or tiers of modality and will be representing them with brackets: [Layer1], [Layer2], and [Layer3] etc. To elaborate this topic, it would be useful to consider a simple proposition John has left Venice: 


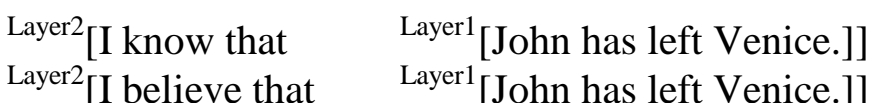

$\begin{array}{lll}\text { Layer3 }^{2} \text { I know that } & { }_{\text {Layer2}}[\text { Mary says that } & { }^{\text {Layer1 }}[\text { John has left Venice.]]] } \\ \text { Layer3 [I believe that } & \text { Layer2 [Mary says that } & \text { Layer1 [John has left Venice.]] }\end{array}$

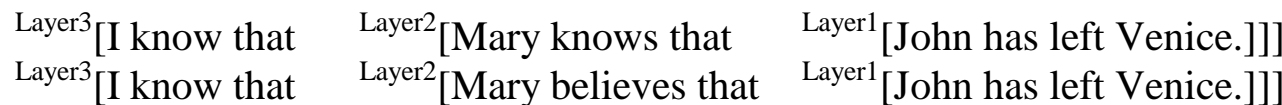

Layer3 [I believe that $\quad$ Layer2 [Mary knows that $\quad{ }^{\text {Layer1 [John has left Venice.]]] }}$

${ }^{\text {Layer3 }}$ [I believe that ${ }^{\text {Layer2 }}$ [Mary believes that $\quad{ }^{\text {Layer1 [John has left Venice.]] }}$

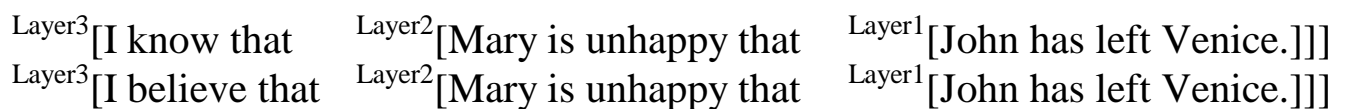

Now, to check the validity of any theory which wants to give an account for subjunctive-indicative divide, for example, one has to see at which layer realis-irrealis contexts are attached to the proposition. It is possible that a sentence has only one layer and modality elements are attached to the proposition at that layer. It is also possible that when a sentence contain different layers the modality items are attached to one of the layers. Generally speaking, if a sentence contains more than one layers - whether hidden of evident - it is the outermost layer (the second or the third) which is likely to contain modality elements, never the innermost (the first) one.

\section{-3. THE OVERALL STRUCTURE OF MODALITY AT THE LEVEL OF VERB IN HINDI}

Unlike languages such as English, where modality is mainly expressed through modals, Hindi has a verbal system which is organized to express different modalities in conjunction with tenses and aspects. Some Hindi moods, for example, are coded in the auxiliary verb which carries a tense as well, while others are coded in the main verb without an auxiliary and hence without any time reference. There is not, however, a clear-cut morphological system which can be thought to be related directly to the mood system in Hindi. Bearing in mind this complexity of the modality system in Hindi, Agha (1998, pg. 123-6) maintains that moods in Hindi should be considered as a derivative category cluster of either different minimal mood categories or as a category in combination with tense and other elements of the verb. In considering the morphological structure of the verb, he further claims that there are only three minimal mood distinctions in Urdu-Hindi ${ }^{7}$, namely, (1) [+/ - imperative], (2) [+/- potential] and (3) [+/- prospective], but we believe that, although this proposal sounds valid on the morphological level, it would be illogical not to recognize the Hindi modality system in its full detail, irrespective of whether all the Hindi moods are coded morphologically or not. For a full picture of the modality system in Hindi ${ }^{8}$, we provide, below, an overall formally-organized structure of the Hindi verbal predicate. ${ }^{9}$

\section{- 3.1 EPISTEMIC MODALITY IN HiNDI}

- 3.1.1 $\mathbf{K}_{\mathbf{s} \cdot \square \boldsymbol{p}^{10}}$ 


\begin{tabular}{|c|c|c|c|c|}
\hline MODALITY & $\begin{array}{l}\text { ASPECT I } \\
\text { HABITUAL }\end{array}$ & $\begin{array}{l}\text { ASPECT II } \\
\text { PROGRESSIVE }\end{array}$ & $\begin{array}{l}\text { ASPECT III } \\
\text { PERFECTIVE }\end{array}$ & ASPECT LESS \\
\hline $\begin{array}{l}\text { (a) } \mathbf{K}_{\mathbf{s}} \cdot \square \boldsymbol{p} \mathrm{t}_{\mathrm{n}-1} \\
\text { INDICATIVE PAST }\end{array}$ & 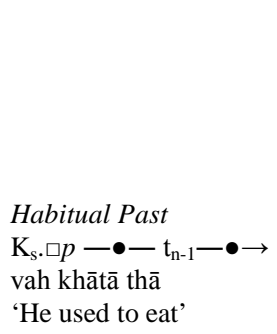 & 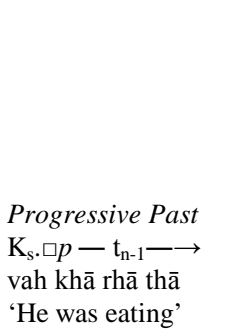 & 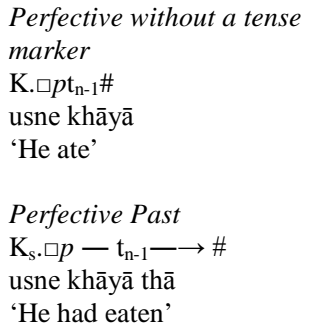 & \\
\hline $\begin{array}{l}\text { (b) } \mathbf{K}_{\mathrm{s}} \cdot \square \boldsymbol{p} \mathrm{t}_{\mathrm{n}} \\
\text { INDICATIVE PRESENT }\end{array}$ & $\begin{array}{l}\text { Habitual Present } \\
\mathrm{K}_{\mathrm{s} .} \square p-\bullet-\mathrm{t}_{\mathrm{n}} \longrightarrow \bullet \rightarrow \\
\text { vah khātā hai } \\
\text { 'He eats' }\end{array}$ & $\begin{array}{l}\text { Progressive Present } \\
\mathrm{K}_{\mathrm{s}} . \square p--\mathrm{t}_{\mathrm{n}} \rightarrow \\
\text { vah khā rahā hai } \\
\text { 'He is eating' }\end{array}$ & $\begin{array}{l}\text { Perfective Present } \\
\mathrm{K}_{\mathrm{s}} \cdot \square p \rightarrow \# \mathrm{t}_{\mathrm{n}} \\
\text { usne khāyā hai } \\
\text { 'He has eaten' }\end{array}$ & \\
\hline
\end{tabular}

\section{1 .2 B. $\diamond p$}

\begin{tabular}{|c|c|c|c|c|}
\hline MODALITY & $\begin{array}{l}\text { ASPECT I } \\
\text { HABITUAL } \\
\end{array}$ & $\begin{array}{l}\text { ASPECT II } \\
\text { PROGRESSIVE }\end{array}$ & $\begin{array}{l}\text { ASPECT III } \\
\text { PERFECTIVE }\end{array}$ & ASPECT LESS \\
\hline $\begin{array}{l}\text { (a) } \mathbf{B} . \forall \boldsymbol{p} \mathrm{t}_{\mathrm{n}} \\
\text { SUBJUNCTIVE: } \\
\text { CONTINGENT }\end{array}$ & $\begin{array}{l}\text { Habitual Subjunctive } \\
\mathrm{B}_{\mathrm{s}} \cdot \diamond p \bullet-\mathrm{t}_{\mathrm{n}}-\bullet \rightarrow \\
\text { vah khātā ho } \\
\text { 'He may be eating } \\
\text { habitually' }\end{array}$ & $\begin{array}{l}\text { Progressive Subjunctive } \\
\mathrm{B}_{\mathrm{s}} \cdot \nabla p--\mathrm{t}_{\mathrm{n}} \rightarrow \\
\text { vah khā rahā ho } \\
\text { 'He may be eating (now)' }\end{array}$ & $\begin{array}{l}\text { Perfective Subjunctive } \\
\mathrm{B}_{\mathrm{s}} \cdot \diamond p \rightarrow \# \mathrm{t}_{\mathrm{n}} \\
\text { usne khāyā ho } \\
\text { 'He may have eaten (now)' }\end{array}$ & Aspectless Subjunctive \\
\hline $\begin{array}{l}\text { (b) B. } \diamond \boldsymbol{p} \mathrm{t}_{\mathrm{n}+1} \\
\text { SUBJUNCTIVE: OPTATIVE }\end{array}$ & & $\begin{array}{l}\mathrm{B}_{\mathrm{s}} \cdot \diamond p \mathrm{t}_{\mathrm{n}+1} \\
\text { vah khātā rahe } \\
\text { 'He may be eating (then)' }\end{array}$ & $\begin{array}{l}\mathrm{B}_{\mathrm{s}} \cdot \diamond p-\longrightarrow \longrightarrow \# \mathrm{t}_{\mathrm{n}+1} \\
\text { vah khā le } \\
\text { 'He may have eaten (by } \\
\text { then)' }\end{array}$ & $\begin{array}{l}\mathrm{B}_{\mathrm{s} \cdot} \diamond p \mathrm{t}_{\mathrm{n}+1} \\
\text { vah khāye } \\
\text { 'He may eat' }\end{array}$ \\
\hline
\end{tabular}

\subsubsection{B. $\square p$}

\begin{tabular}{|c|c|c|c|c|}
\hline MODALITY & $\begin{array}{l}\text { ASPECT I } \\
\text { HABITUAL }\end{array}$ & $\begin{array}{l}\text { ASPECT II } \\
\text { PROGRESSIVE } \\
\end{array}$ & $\begin{array}{l}\text { ASPECT III } \\
\text { PERFECTIVE }\end{array}$ & ASPECT LESS \\
\hline $\begin{array}{l}\text { (a) B. } \square \boldsymbol{p} t_{n} \\
\text { PRESUMPTIVE }\end{array}$ & $\begin{array}{l}\text { Habitual Presumptive } \\
\mathrm{B}_{\mathrm{s} .} \cdot p \mathrm{t}_{\mathrm{n}-1}-\bullet-\mathrm{t}_{\mathrm{n}} \longrightarrow \bullet \\
\text { vah khātā hogā } \\
\text { 'He must be eating } \\
\text { habitually' }\end{array}$ & $\begin{array}{l}\text { Progressive Presumptive } \\
\mathrm{B}_{\mathrm{s}} \cdot \square p \mathrm{t}_{\mathrm{n}-1}-1-\mathrm{t}_{\mathrm{n}} \rightarrow \\
\text { vah khā rahā hogā } \\
\text { 'He must be eating' }\end{array}$ & $\begin{array}{l}\text { Perfective Presumptive } \\
\mathrm{B}_{\mathrm{s}} \cdot \square p-\longrightarrow \# \mathrm{t}_{\mathrm{n}} \\
\text { usne khāyā hogā } \\
\text { 'He must have eaten' }\end{array}$ & Aspectless future \\
\hline $\begin{array}{l}\text { (b) B. } \square p t_{n+1} \\
\text { FUTURE }\end{array}$ & $\begin{array}{l}\mathrm{B}_{\mathrm{s} .} \square p \mathrm{t}_{\mathrm{n}-1}-\bullet-\mathrm{t}_{\mathrm{n}} \longrightarrow \bullet \rightarrow \\
\text { vah khāyā karegā } \\
\text { 'He will be eating } \\
\text { frequently' }\end{array}$ & $\begin{array}{l}\mathrm{B}_{\mathrm{s} \cdot \square p} \mathrm{t}_{\mathrm{n}}-\longrightarrow \mathrm{t}_{\mathrm{n}+1} \\
\text { vah khātā rahegā } \\
\text { 'He will continue eating' }\end{array}$ & 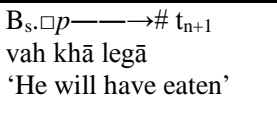 & $\begin{array}{l}\mathrm{B}_{\mathrm{s} \cdot \square p \mathrm{t}_{\mathrm{n}+1}} \\
\text { vah khāegā } \\
\text { 'He will eat' }\end{array}$ \\
\hline
\end{tabular}

\subsection{DeONTIC ModAlity IN Hindi ${ }^{12}$}

\subsection{1 $\mathbf{W}_{\mathrm{s}} \cdot \square ! p \mathbf{t}_{\mathrm{n}+\mathbf{1}^{13}}$}

\begin{tabular}{|c|c|c|c|c|}
\hline MODALITY & $\begin{array}{l}\text { ASPECT I } \\
\text { HABITUAL }\end{array}$ & $\begin{array}{l}\text { ASPECT II } \\
\text { PROGRESSIVE }\end{array}$ & $\begin{array}{l}\text { ASPECT III } \\
\text { PERFECTIVE }\end{array}$ & ASPECT LESS \\
\hline IMMEDIATE COMMAND & $\begin{array}{l}\text { Habitual immediate } \\
\text { command } \\
\mathrm{W}_{\mathrm{s} .} \cdot \mathrm{p} \mathrm{t}_{\mathrm{n}}-\bullet-\mathrm{t}_{\mathrm{n}+1} \longrightarrow \bullet \rightarrow \\
\text { (tū) ise khāyā kar } \\
\text { (tum) ise khāyā karo } \\
\text { (āp) ise khāyā kījie } \\
\text { 'Make it a habit to eat it!' }\end{array}$ & $\begin{array}{l}\text { Progressive immediate } \\
\text { command } \\
\mathrm{W}_{\mathrm{s} \cdot \square ! p} \mathrm{t}_{\mathrm{n}}-\longrightarrow \longrightarrow \mathrm{t}_{\mathrm{n}+1} \\
\text { (tū) ise khātā rah } \\
\text { (tum) ise khāte raho } \\
\text { (āp) ise khāte rahie } \\
\text { 'Continue eating it!' }\end{array}$ & $\begin{array}{l}\text { Perfective immediate } \\
\text { command } \\
\mathrm{W}_{\mathrm{s} \cdot \square ! p-— \longrightarrow} \longrightarrow \mathrm{t}_{\mathrm{n}+1} \\
(\mathrm{tū}) \text { ise khā le } \\
\text { (tum) ise khā lo } \\
\text { (āp) ise khā lījie } \\
\text { 'Eat it up!' }\end{array}$ & $\begin{array}{l}\text { Aspectless immediate } \\
\text { command } \\
\mathrm{W}_{\mathrm{s} \cdot \square !} \cdot \mathrm{pt}_{\mathrm{n}+1} \\
\text { (tū) ise khā } \\
\text { (tum) ise khāo } \\
\text { (āp) ise khāie } \\
\text { 'Eat it!' }\end{array}$ \\
\hline
\end{tabular}


3.2.2 $\mathbf{W}_{\mathrm{s}} \cdot \square ! p \mathbf{t}_{\mathrm{n}+2}$

\begin{tabular}{|c|c|c|c|c|}
\hline MODALITY & $\begin{array}{l}\text { ASPECT I } \\
\text { HABITUAL }\end{array}$ & $\begin{array}{l}\text { ASPECT II } \\
\text { PROGRESSIVE }\end{array}$ & $\begin{array}{l}\text { ASPECT III } \\
\text { PERFECTIVE }\end{array}$ & ASPECT LESS \\
\hline DEFERRED COMMAND & $\begin{array}{l}\text { Habitual deferred } \\
\text { command } \\
\mathrm{W}_{\mathrm{s} \cdot \square ! p} \mathrm{t}_{\mathrm{n}+1}-\bullet-\mathrm{t}_{\mathrm{n}+2}-\bullet \rightarrow \\
\text { (tum) ise khāyā karo } \\
\text { 'Make it a habit to eat it!' }\end{array}$ & $\begin{array}{l}\text { Progressive deferred } \\
\text { command } \\
\mathrm{W}_{\mathrm{s} \cdot \square ! p \mathrm{t}_{\mathrm{n}+1}-\longrightarrow} \longrightarrow \mathrm{t}_{\mathrm{n}+2} \\
\text { (tum) ise khātā rahnā } \\
\text { 'Continue eating it!' }\end{array}$ & 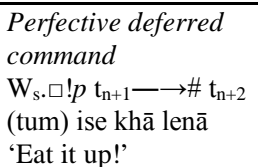 & $\begin{array}{l}\text { Aspectless deferred } \\
\text { command } \\
\mathrm{W}_{\mathrm{s} \cdot \square ! p \mathrm{t}_{\mathrm{n}+2}} \\
\text { (tum) ise khā } \\
\text { 'Eat it!' }\end{array}$ \\
\hline
\end{tabular}

3.2.3 $\mathbf{W}_{\mathbf{s}} . \diamond ! p \mathbf{t}_{\mathbf{n}+1}$

\begin{tabular}{|c|c|c|c|c|}
\hline MODALITY & $\begin{array}{l}\text { ASPECT I } \\
\text { HABITUAL }\end{array}$ & $\begin{array}{l}\text { ASPECT II } \\
\text { PROGRESSIVE }\end{array}$ & $\begin{array}{l}\text { ASPECT III } \\
\text { PERFECTIVE }\end{array}$ & ASPECT LESS \\
\hline $\begin{array}{l}\text { COMMAND WITH } \\
\text { SUBJUNCTIVE }\end{array}$ & $\begin{array}{l}\text { Habitual subjunctive } \\
\text { command } \\
\mathrm{W}_{\mathrm{s} .} \diamond ! p \mathrm{t}_{\mathrm{n}}-\bullet-\mathrm{t}_{\mathrm{n}+1}-\bullet \rightarrow \\
\text { (āp) ise khāyā karẽ } \\
\text { 'Make it a habit to eat it!' }\end{array}$ & $\begin{array}{l}\text { Progressive subjunctive } \\
\text { command } \\
\mathrm{W}_{\mathrm{s}} \diamond \text { ! } p \mathrm{t}_{\mathrm{n}}-\longrightarrow \mathrm{t}_{\mathrm{n}+1} \\
\text { (āp) ise khāte rahẽ } \\
\text { 'Continue eating it!' }\end{array}$ & $\begin{array}{l}\text { Perfective subjunctive } \\
\text { command } \\
\mathrm{W}_{\mathrm{s}} \cdot \diamond ! p \mathrm{t}_{\mathrm{n}} \longrightarrow \longrightarrow \# \mathrm{t}_{\mathrm{n}+1} \\
(\overline{\mathrm{a}} \mathrm{p}) \text { ise khā lẽ } \\
\text { 'Eat it up!' }\end{array}$ & $\begin{array}{l}\text { Aspectless subjunctive } \\
\text { command } \\
\mathrm{W}_{\mathrm{s} .} \diamond \mathrm{pt}_{\mathrm{n}-1} \\
\text { (āp) ise khāẽ } \\
\text { 'Eat it!' }\end{array}$ \\
\hline
\end{tabular}

3.2.4 $\mathbf{W}_{\mathrm{s}} . \diamond ! p \mathbf{t}_{\mathrm{n}+1}$

\begin{tabular}{|c|c|c|c|c|}
\hline MODALITY & $\begin{array}{l}\text { ASPECT I } \\
\text { HABITUAL }\end{array}$ & $\begin{array}{l}\text { ASPECT II } \\
\text { PROGRESSIVE }\end{array}$ & $\begin{array}{l}\text { ASPECT III } \\
\text { PERFECTIVE }\end{array}$ & ASPECT LESS \\
\hline $\begin{array}{l}\text { COMMAND WITH } \\
\text { CONTINGENT }\end{array}$ & $\begin{array}{l}\text { Habitual contingent } \\
\text { command } \\
\mathrm{W}_{\mathrm{s}} \cdot \vee ! p \mathrm{t}_{\mathrm{n}-1}-\bullet-\mathrm{t}_{\mathrm{n}}-\bullet \rightarrow \\
\text { (āp, tum) ise khāyā karte } \\
\text { 'You should have made it a } \\
\text { habit to eat it.' }\end{array}$ & $\begin{array}{l}\text { Progressive contingent } \\
\text { command } \\
\mathrm{W}_{\mathrm{s} .} \diamond ! p \mathrm{t}_{\mathrm{n}-1}--\mathrm{t}_{\mathrm{n}} \rightarrow \\
\text { (āp, tum) ise khāte rahte } \\
\text { 'You should have } \\
\text { continued eating it.' }\end{array}$ & $\begin{array}{l}\text { Perfective contingent } \\
\text { command } \\
\mathrm{W}_{\mathrm{s} .} \diamond ! p \mathrm{t}_{\mathrm{n}} \longrightarrow \rightarrow \# \mathrm{t}_{\mathrm{n}+1} \\
\text { (āp, tum) ise khā lete } \\
\text { 'You should have eaten it } \\
\text { up.' }\end{array}$ & $\begin{array}{l}\text { Aspectless contingent } \\
\text { command } \\
\mathrm{W}_{\mathrm{s}} . \triangleright ! p \mathrm{t}_{\mathrm{n}+1} \\
\text { (āp, tum) ise khāte } \\
\text { 'You should have eaten it.' }\end{array}$ \\
\hline
\end{tabular}

\section{THE MODAL MEANINGS OF THE HINDI VERBAL PREDICATES}

In the light of the classification of Hindi verbal predicates presented above, we can, therefore, have the following list of different types of modality in Hindi, irrespective of whether all the modality types are coded at the morphological level or not. As can be observed from the meanings attributed to the following modality types, their semantic elements are, however, almost always part of the tense and aspect meanings of the verbal predicate. To assert the existence of an action $x$ or a state of affairs $s$ is also to assert their existence at one point in time, i.e. $t_{n-1}, t_{n}, t_{n+1}$, or $t_{n+2}$ etc. As noted above, the sentential modality makes a grounding frame for a proposition, a surrounding envelope or attitude asserted by a speaker. Modality, according to Palmer ${ }^{14}$, relates semantically to the whole sentence rather than to the verb alone. In other words, although it is possible to establish a direct link between some parts of the verbal predicate and its corresponding mood, it is too difficult to assign every element of the verbal predicates a semantic value and give an account of the modal system in Hindi in morphological terms only.

4.1. $\mathbf{K}_{\mathbf{s}} \square \boldsymbol{p}$ : I know that necessarily $p$

$$
\text { (a) } \mathbf{K}_{\mathrm{s}} \cdot \square \boldsymbol{p} \mathrm{t}_{\mathrm{n}-1}
$$


[MODAL MEANING: In order for you to take notice of it and act accordingly, I want to communicate to you that I know that $\square p$ (i.e. it is the case that necessarily- $p$ ) which is tantamount to $\mathrm{K}_{\mathrm{s} .} \neg \diamond \neg p$ (i.e. I know that it is not-possible that not- $p$ ). I, furthermore, assert and vouch for the veridicality of $p$. As far as the time reference of the action is concerned, I affirm that the action(s) or state(s) of affairs described in $p$ necessarily took place at $t_{n-1}$ and that although I do not make any claims such as whether they are continuing any longer at $t_{n}$ or not, my not making such a claim can be taken to mean that they certainly are not. In a revised Reichenbachian ${ }^{15}$ terminology, the relation between event time $(\mathrm{E})$, speech time $(\mathrm{S})$ and reference time $(\mathrm{R})$ of this modality type can be represented in the following manner: habitual and progressive aspects (E,R_S), perfective aspect (E_R_S) ${ }^{16}$ In aspectual terms, the relation between E and R may vary as per Hindi aspects: in the habitual aspect $\mathrm{R}$ cannot be considered a point in time but rather a period containing different points in time to which different occurrences of $\mathrm{E}$ can be related; in the progressive aspect $\mathrm{E}$ and $\mathrm{R}$ are contemporaneous; and in the perfective aspect $\mathrm{E}$ has a termination point at $\mathrm{R}$. The past indicatives with or without three aspects belong to this mood category.]

(b) $\mathbf{K}_{\mathrm{s} \cdot \square p \mathrm{t}_{\mathrm{n}}}$

[MODAL MEANING: In order for you to take notice of it and act accordingly, I want to communicate to you that I know that $\square p$ (i.e. it is the case that necessarily $p$; in other words, it is possibly not the case that not- $p: \neg \diamond \neg p)$. I, furthermore, assert and vouch for the veridicality of $p$. In the case of a habitual aspect, the action(s) described in $p$ take place frequently at $t_{n}$. This means that action(s) necessarily took place at least once at $t_{n-}$ 1, that action(s) may or may not be taking place contemporaneously to the utterance and are most likely to take place after $t_{n}$. In the case of a continuous or progressive aspect of the verb, the action(s) described in the utterance have not been terminated at $t_{n}$, whereas in the case of a perfective aspect they have a termination point at $t_{n}$. The veridicality of the states of affairs contained in the proposition $p$, however, holds for the time $t_{n}$ only, and their pre-or-post- $t_{n}$-existence cannot be asserted but solely inferred. The time framework of this mood can, therefore, be represented in the following schemata: habitual and progressive (S,R,E) and perfective E_R,S. The present indicatives with three aspects fall into this mood category.]

- 4.2. B $_{\mathrm{s}} \diamond \boldsymbol{p}:$ I believe that possibly $p$

(a) $\mathbf{B}_{\mathrm{s}} \bullet \boldsymbol{p} t_{n}$

[MODAL MEANING: For all the information that I have, I believe that at $t_{n}$ it is the case that possibly- $p$, although I don't know either that necessarily-p (i.e. $\neg \neg \mathrm{K}_{\mathrm{s}} . \square p$ ) or that necessarily-not- $p$ (i.e. $\neg \mathrm{K}_{\mathrm{s} .} \cdot \neg p$ ), and that this belief is not-necessarily-not- $p$ (i.e. $\mathrm{B}_{\mathrm{s} .} \neg \square$ $\neg p$ ). I, therefore, in order for you to take notice of it and act accordingly want to communicate to you that, although I do not know it, I nonetheless believe that the action(s) or state(s) of affairs described in $p$ possibly exist at $t_{n}$. For the action(s) reported in $p$, given my beliefs and from the information that I possess, it can be said that their beginning point may have been at $t_{n-1}$ and that actions with perfective aspect may have had an endpoint at $t_{n}$ and action(s) with habitual and progressive aspects may be likely to continue after $t_{n}$. The schemata representing all three aspects in this mood category should look exactly the same as that of the previous category (4.1.b), i.e. 
habitual and progressive (S,R,E) and perfective E_R,S. The subjunctives with three aspects fall into this category.]

(b) $\mathbf{B}_{\mathrm{s}} \cdot \diamond \boldsymbol{p} t_{n+1}$

[MODAL MEANING: For all the information that I have, I believe that it is the case that possibly- $p$ (i.e. it is the case that not-necessarily-not- $p$ : $\diamond p \leftrightarrow \neg \square \neg$ )). The difference between the former category (4.2.a) and the present one can be understood in the following way: while in the previous category I don't know that $p$ but I may have the possibility, if I desire, of knowing if- $p$ or if-not- $p$ since the veridicality of possibly- $p$ and possibly-not- $p$ is anchored at the time of utterance $t_{n}$, in the present category I may not know it since the action(s) or state(s) of affairs reported in $p$ do not exist at $t_{n}$ and will only possibly take place only at $t_{n+1}$. I therefore want to communicate in order for you to take notice of it and act accordingly that I believe that the action(s) or state(s) of affairs described in $p$ may take place or exist at $t_{n+1}$. This is also called an optative mood. For the action(s) reported in $p$, given my beliefs, it can be said that it is likely that, as per their aspectual nature, they may continue after $t_{n+1}$.]

4.3. $\mathbf{B}_{\mathbf{s}} \cdot \square$ : I believe that necessarily $p$

(a) $\mathbf{B}_{\mathrm{s}} \cdot \square \boldsymbol{p} \mathrm{t}_{\mathrm{n}}$

[MODAL MEANING: For all the information that I have, I believe that it is the case that $\square p$ which is tantamount to $\mathrm{B}_{\mathrm{s}} . \neg \neg p$ (i.e. I believe that it is not-possible that not- $p$ ), although I do not know whether $p$ or not- $p$. I, therefore, want to communicate to you in order for you to take notice of it and act accordingly that, although I don't know it, I believe that the action(s) or state(s) of affairs described in $p$ necessarily exist at $t_{n}$. For the action(s) reported in $p$, given my beliefs and from the information that I possess, it is safer to hypothesize that their beginning point was at $t_{n-1}$ and that, except for action reported in a perfective aspect, they are likely to continue after $t_{n}$. The schemata representing all three aspects in this mood category should look exactly the same as that of the previous categories (4.1.b) and (4.2.a), i.e. habitual and progressive (S,R,E) and perfective E_R,S. The presumptives with all three aspects fall into this mood category.]

(b) $\mathbf{B}_{\mathrm{s}} \cdot \square \boldsymbol{p} \mathrm{t}_{\mathrm{n}+1}$

[MODAL MEANING: For all the information that I have, I believe that it is the case that necessarily $p$ and it is not-possible that not-p (i.e. $\square p \leftrightarrow \leftrightarrow \neg \diamond \neg p$ ), although I cannot know it since the action(s) or state(s) of affairs reported in $p$ do not exist at $t_{n}$ and will take place only at $t_{n+1}$. I, therefore, want to communicate in order for you to take notice of it and act accordingly that I believe that the action(s) or state(s) of affairs described in $p$ will necessarily take place or exist at $t_{n+1}$. For the action(s) reported in $p$, given my beliefs, it is safer to hypothesize that it is likely that, as per their aspectual nature, they may continue after $t_{n+1}$. The schemata of this mood category should look like the following: S_R,E. The future tense comes in conjunction with this mood category.] 
(a) $\quad \mathbf{W}_{\mathrm{s}} \cdot \square ! p t_{n+1}$

[MODAL MEANING: By an utterance carrying deontic elements of this category, all I want is to ask you to recognize my intention and obligatorily carry out an action $x$ immediately after the time of utterance at $t_{n+1}$. The speaker recognizes that the addressee is in a position of carrying out the task at time $t_{n+1}$.]

(b) $\quad \mathbf{w}_{\mathrm{s}} \cdot \square ! p t_{n+2}$

[MODAL MEANING: By an utterance carrying deontic elements of this category, all I want is to ask you to obligatorily carry out an action $x$ at $t_{n+2}$. The speaker recognizes that the addressee is in a position of carrying out an action $x$, but either he considers it not necessary to carry out $x$ immediately or he recognizes that it will not be possible for the addressee to carry out $x$ immediately after the utterance and therefore asks him to obligatorily carry out $x$ at a future point in time $t_{n+2}$.]

4.5. $\mathrm{w}_{\mathrm{s}} \bullet$ ! $\boldsymbol{p}$ : Possibly carry out $x$

(a) $\quad \mathbf{w}_{\mathrm{s} \cdot} \diamond ! p t_{n}$

[MODAl MEANING: By the utterance Do $x$, if possible! all I want is to ask you to possibly carry out an action $x$ immediately after $t_{n}$. The speaker asks the addressee to possibly carry out the action immediately after the utterance, $t_{n+1}$. In contrast to (4.4.a), this is a command with possibility. The speaker, therefore, while asking the addressee to carry out an action $x$, gives him also the possibility of not fulfilling the obligation, if he fails to carry out the desired action.]

(b) $\quad \mathbf{w}_{\mathrm{s}} \bullet$ $\diamond \mathbf{p} t_{n}$

[MODAL MEANING: The speaker wants the addressee to possibly carry out the action $x$ immediately after $t_{n}$. Like (4.5.a), this too is a command with the possibility of carrying out the desired action, though its meaning is obtained by a counterfactual reasoning. It is therefore inherently of a conditional nature and its implicature is the following: 'You were obliged to carry out $x$, but so far you haven't. Therefore, it would be nice, if you could possibly carry out $x$ now.']

\section{n5. THE VARIOUS USES OF THE SUBJUNCTIVE IN HINDI}

As is quite common in most languages of the world, the indicative-subjunctive divide in Hindi, too, is not always a clear-cut one. On the whole, though, it can be affirmed that the realis/irrealis divide is an important tool to account for the Hindi subjunctive and indicative moods. Roughly speaking, all realis contexts in Hindi tend to select an indicative mood, whereas all irrealis contexts of the proposition require a subjunctive mood of the verb. Furthermore, the presence or absence of either indicative or subjunctive in a matrix clause is also a determining factor. In syntactic terms, the Hindi indicative mood normally appears in a matrix clause, whereas the subjunctive mood is found in subordinate clauses, except for optatives and polite commands where it may also be used in a matrix clause or in subordinate clauses which seem to be matrix ones. 
While talking about the role of modality in syntax, it should be noted that modality may or may not be found at the level of a sentence. As we have conceived it in this paper, modality is thought to be related to the speaker's attitude about the proposition expressed at the level of utterance and it cannot therefore be limited to the level of a sentence which is in most cases without any reference to the speaker, although some syntactic observations can be made regarding its various uses along the line.

\section{— 5.1 FACTIVITY AND THE SUBJUNCTIVE}

The Hindi subjunctive follows the same pattern found in many languages, such as Italian, French and Spanish, in which the subjunctive is abundantly used, with the exception of a few cases in which it seems to have been influenced by the English language. To understand the use of the subjunctive mood in Hindi, the fourfold classification of matrix verbs in English presented by Hooper (1975) can be useful: (1) Assertive Factive (semifactive) ${ }^{17}$, (2) Non-assertive Factive (true factive $^{18}$, (3) Assertive Non-factive ${ }^{19}$, (4) Non-assertive Non-factive ${ }^{20}$. As can be seen from the following examples (1) and (2), the Hindi indicative is the only possibility in subordinate clauses which have an assertive factive (semifactive) or a non-assertive factive (true factive) in their matrix clauses.

(1) mohan jāntā hai ki mīrā ne ciț̣hì likhī hai

Mohan know pres-indthat Mira-erg letter write-perfv-part pres-ind

'Mohan knows that Mira has written the/a letter.'

(2) mohan ko afsos hai ki mīrā ne cițthī likhī hai

Mohan-dat sorrow pres-ind that Mira-erg letter write-perfv-part pres-ind 'Mohan is sorry that Mira has written the/a letter.'

The non-assertive non-factive verbs in the matrix clause, as in (3), however, select a subjunctive form of the verb at the level of subordinate clause:

(3) yah sambhav/asambhav hai ki mīrā ne citṭhì likhī ho

this possible/impossible pres-ind that Mira-erg letter write-perfv-part pres-sub 'It is possible/impossible that Mira may have written the/a letter.'

Some weak assertive non-factive verbs in the matrix clause, such as the one in (4), require the indicative in the subordinate clause, whereas others, for example in (5), may take either the indicative or the subjunctive.

(4) mã̃ soctā hĩ $\quad$ ki vah calā gayā hai

I think aux that he gone pres-ind

'I think that he has gone.'

(5) mujhe lagtā hai ki vah calā gayā hai/ho

I-dat appears is that he gone pres-ind/sub

'It seems to me that he has gone.' 


\section{- 5.2 VOLITIONAL VERBS AND THE SUBJUNCTIVE}

If the matrix clause of a Hindi sentence contains a volitional or desiderative verb ${ }^{21}$, the subordinate clause requires the subjunctive. In such cases, the volitional verb of the matrix clause is normally in the present tense, but can also be in the past, as in (6), or future, as in (7) and the subordinate clause has a subjunctive verb form. The subjunctive verb form in such cases carries an element of deontic modality rather than that of epistemic modality, as it contains the speaker's will regarding the addressee's future actions: the speaker wants the addressee to carry out an action which is to take place after the time of utterance:

(6) mohan cāhtā hai/thā ki rām jāe

Mohan want pres-ind/past-ind that Ram go-sub

'Mohan wants/ wanted Ram to go.'

(7) mohan cāhegā ki rām jāe

Mohan want-fut that Ram go-sub

'Mohan will want Ram to go.'

The formal structure of the sentences (6) and (7) should look like the following:

$$
/ \mathrm{K}_{\mathrm{s} .} \square p . / \mathrm{W}_{\mathrm{pm} .} \cdot \square p . / \diamond ! p /
$$

i.e. the speaker knows that it is necessarily the case that the person referred to, i.e. Mohan, wanted/wants/will want Ram to possibly carry out the action $x$.

The volitional verb in the matrix clause can also be in the future or may have future time reference. In such cases, however, the speaker's beliefs rather than knowledge is involved.

$$
/ \mathrm{B}_{\mathrm{s}} . \square p . / \mathrm{W}_{\mathrm{pm} .} \cdot \square p . / \diamond ! p /
$$

i.e. the speaker believes that it is necessarily the case that the person referred to wanted/wants/will want him/her to possibly carry out the action $x$.

Questions and commands with the subjunctive verb form also contain a volitional verb in the matrix clause. Examples (9) and (10), for instance, are respectively the interrogative and imperative forms of the affirmative (8). In the case of questions with the subjunctive, the speaker may want to know whether his addressee wants him to carry out the action or he may simply want to get permission to carry it out and in the case of an imperative with the subjunctive the speaker asks the addressee to possibly carry out the action.

(8) āp cāhte hã̃ ki mã̃ jā̃̄

you want pres-ind that I go-sub

'You want me to go.'

(9) kyā mã̃ jā̃̄

ynq I go-sub

'Do you want me to go?'

'Can/may I go?' 
'Will you go, please?'/ 'You may go.'

\section{- 5.3 SuBJUNCTIVE AND CONDITIONALS}

Hindi has a type of conditional which may exhibit subjunctive verb forms both in protasis or antecedent (if you go to Italy) and apodosis or consequent (you will see Rome). The subjunctive in protasis indicates that the proposition contained in that part refers to a possible or desirable world and corresponds with the indicative found in protasis in languages such as English and Italian.

$$
\begin{aligned}
& \text { agar } \bar{a} p \quad c \bar{a} h \tilde{e} \quad \text { to } m \tilde{a} \tilde{\imath} \\
& \text { if } j \tilde{a} \overline{\bar{u}} \\
& \text { 'I can go, if you want.' }
\end{aligned}
$$

Another type of conditional contain the subjunctive in protasis only which exhibits the possibility of the action or states of affairs mentioned. By using the subjunctive verb form in the example (12), the speaker attaches a modal meaning to the sentence which expresses a possibility that the person referred to might come.

$$
\begin{aligned}
& \text { (12) agar vah āe to mujhe bulānā } \\
& \text { if he come(sub) then I-acc call-inf } \\
& \text { 'Call me, if he comes.' }
\end{aligned}
$$

In Hindi, the subjunctive can also be found in consequent (or apodosis) only, which is the remnant of a full conditional sentence and therefore requires the antecedent in order to be fully interpreted. This form is prevalently found in commercial advertisements. The examples (13) and (14) are the remnants of conditional sentences and require a protasis to be understood fully.

(13) $\tilde{\bar{a}} \mathrm{c}$ din mẽ javānī lāe

five days in youthfulness bring-sub

'It may bring you youthfulness in five days!'

(14) ek hafte mẽ lakhpati banẽ

one week in millionaire become-sub

'Become a millionaire in a week!'

\section{- 5.4 SUBJUNCTIVE AND NEGATION}

As we have discussed elsewhere ${ }^{22}$, Hindi possesses three negative markers, namely nahī, mat and

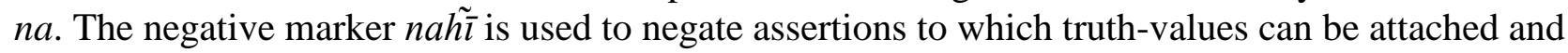
it expresses an epistemic necessity. The negative marker mat expresses solely deontic necessity. The negative marker $n a$, on the other hand, expresses both epistemic and deontic possibilities; in the case of epistemic possibility na expresses that it is possibly not the case that $p$, whereas in the case of deontic possibility it means 'possibly don't carry out the action $x$ '. The distribution of negative markers in Hindi, thus, can be represented in the following way (Sharma, 1999, pg. 292): 


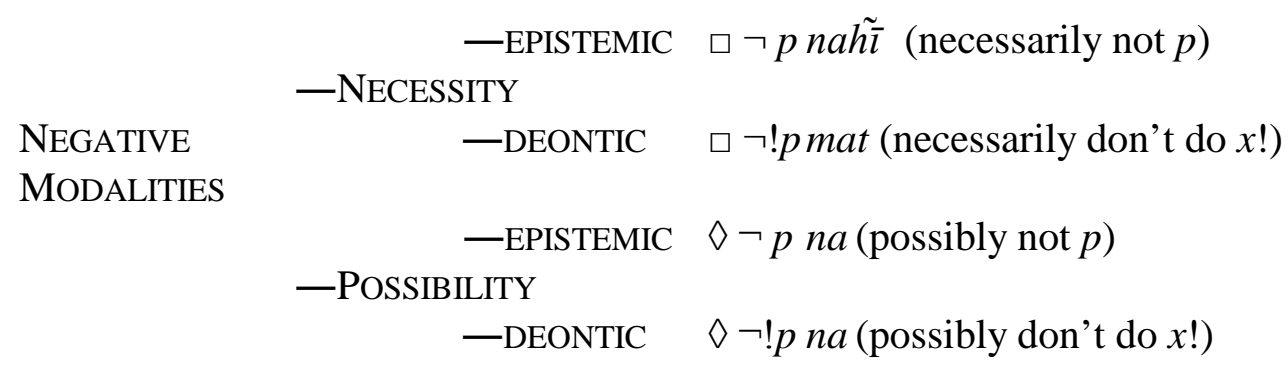

Since the subjunctive mood can be employed to express possibility only, rather than to express a necessity, $\square$ is the negative marker which is prevalently found in use. ${ }^{23}$ The negative marker $\square$ can, therefore, be found in cases of both epistemic and deontic possibilities. In a study on negative modality in Hindi and Bangla, Van der Auwera (1996) suggests that there doesn't seem to be any difference whatsoever between the Hindi negative markers nahĩ and na. However, this doesn't seem to be the case. As can be seen in (15) and (16), the negative marker na cannot be used to express epistemic necessity:

(15) yah śahar sundar nẫ̄/* na hai

this city beautiful NEG pres-ind

'This city is not beautiful.'

(16) vah angrezī nah̃̄ $/ *$ na jāntā (hai)

he English NEG know pres-ind

'He doesn't know English.'

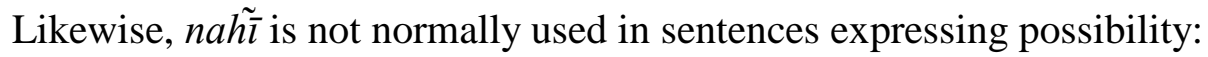

$\begin{array}{lllll}\text { (17) ho saktā hai ki vah na/nahī } & \bar{a} e \\ \text { be possible pres-ind that he NEG } & \text { come-sub }\end{array}$

'It is possible that he won't come.'

\section{CONCLUSION}

As we have seen above, a correct analysis of the subjunctive can be conceived in terms of modality, rather than solely syntactically. Some syntactic aspects of the subjunctive can be found at the level of the matrix verb, but it is the speaker - whether referred to in the utterance or not - who is responsible for the selection of the subjunctive instead of the indicative. The subjunctive is employed by the speaker when he wishes to express either the epistemic or deontic possibility of the veridicality of the proposition contained in the utterance and the indicative is used by him to express either epistemic or deontic necessity of the veridicality of the proposition. Like many other languages which have the subjunctive/indicative divide, the Hindi subjunctive is employed by the speaker to express modal epistemic and deontic possibilities of the proposition, as well as his wishes. They are, furthermore, used for making commands and polite questions.

\section{REFERENCES}

Agha, A. 1998. Form and function in Urdu-Hindi verb inflection. In R. Singh (ed.) The yearbook of South Asian languages and linguistics, 1998, 105-133, New Delhi: Sage Publications.

Bhatia, T. K. 1995. Negation in South Asian languages. Patiala: Indian Institute of Language studies. 
Chierchia, G. and S. McConnell-Ginet. 2000. Meaning and grammar. Cambridge, MA: MIT Press. Second edition.

Cinque, G. 1995. Italian syntax and universal grammar. Cambridge: Cambridge University Press.

Comrie, B. 1976. Aspect. Cambridge: Cambridge University Press.

Comrie, B. 1985. Tense. Cambridge: Cambridge University Press.

Dahl, Ö. 1985. Tense and aspect systems. Oxford: Basil Blackwell.

Giorgi, A. and F. Pianesi. 1997. Tense and aspect. Oxford: Oxford University Press.

Grice, H. P. 1989. Studies in the way of words. Cambridge, MA: Harvard University Press.

Hintikka, J. 1962. Knowledge and belief. Ithaca, NY: Cornell University Press.

Hoe, L. 1997. Adverbs and modality in English. London: Longman.

Hooper, J. B. 1975. On assertive predicates. In J. P. Kimball (ed.), Syntax and semantics. Vol. 4. 91-124, New York: Academic Press.

Horn, L. 1972. On the semantic properties of logical operators in English. Distributed by Indiana University Linguistics Club, 1976.

Horn, L. 1989. A natural history of negation. Chicago: Chicago University Press.

Jespersen, O. 1924. The philosophy of grammar. London: Allen and Unwin.

Kachru, Y. 1980. Aspects of Hindi grammar. New Delhi: Manohar.

Kratzer, A. 1981. The notional category of modality. In H. Eikmeyer and H. Rieser (eds.) Words, worlds, and contexts: new approaches in word semantics, Berlin: Walter de Gruyter.

Lyons, J. 1977. Semantics. Vol. 2. Cambridge: Cambridge University Press.

McGregor, R. S. 1972. Outline of Hindi grammar. Oxford: Clarendon Press.

Mascica, C. P. 1991. The Indo-Aryan languages. Cambridge: Cambridge University Press.

Mohanan, T. 1994. Argument structure in Hindi. Stanford: CSLI Publications.

Palmer, R. 1986. Mood and modality. Cambridge: Cambridge University Press.

Perkins, M. R. 1983. Modal expressions in English. Norwood, NJ: Ablex Publishing Corporation.

Rescher, N. 1968. Topics in philosophical logic. Dordrecht: Reidel.

Shapiro, M. C. 1989. A primer of modern standard Hindi. Delhi: Motilal Banarsidass Publishers.

Sharma, G. 1999. A pragmatic survey of Hindi imperatives. Annali di Ca' Foscari, XXXVIII, 3, 245-316.

Sharma, G. 2000. Pragmatic explanations for expressing obligations of the agent referred to in Hindi. In R. Singh (ed.) The Yearbook of South Asian Languages and Linguistics, 2000, 185202, London-New Delhi: Sage Publications.

Van der Auwera, J. 1996. Modality: the three-layered scalar square. Journal of semantics 13: 181-195.

Van der Auwera, J. 1996. Negating dynamic and deontic modality in Hindi-Urdu and Bangla. In A. Abbi (ed.) (forthcoming), Delhi: Motilal Banarsidass Publishers.

Van der Auwera, J. and V. A. Plungian. 1998. Modality’s semantic map. Linguistic typology 2: 79-124.

Von Wright, G. H. 1951. An essay in modal logic. Amsterdam: North-Holland Publishing Company.

\footnotetext{
${ }^{1}$ I am greatly indebted to Elena Bashir for comments on a draft of the paper. Needless to say, I am responsible for any remaining errors.

${ }^{2}$ The question whether the Interrogative is a mood or sentence type remains unanswered in that there are languages in which there are no morphological devices used to make questions - only the intonation pattern makes the affirmative sentence interrogative - and therefore no correspondence can be established between the interrogative sentence and the mood. Palmer (1986, pg. 31) expresses the similar ideas on this point: "Yet it must be admitted that formally the
} 
interrogative is unrelated to the modal system of many languages and that semantically it seems to belong to discourse rather than modality, to matters of asking questions, giving replies, etc.”

${ }^{3}$ According to van der Auwera and Plungian (1998, 82), there can be at least eight categories of epistemic and deontic necessity and possibility: (1) Participant-internal possibility (Dynamic possibility, Ability, Capacity), (2) Participantinternal necessity (need), (3) Participant-external possibility, (4) Participant-external necessity, (5) Deontic possibility (permission), (6) Deontic necessity (Obligation), (7) Epistemic possibility (Uncertainty), (8) Epistemic necessity (Probability).

${ }^{4}$ Discussing indicative, subjunctive and imperative moods in English, Jespersen (1924: 313) points out that: "They express certain attitudes of mind of the speaker towards the content of the sentence, though in some the choice of mood is determined not by the character of the clause itself and its relation to the main nexus on which it is dependent. Further, it is very important that we speak of 'mood' only if the attitude of mind is shown in the form of the verb: mood thus is a syntactic, not a notional category” and presents a list of different moods, dividing them into two main sets: moods containing an element of will and those containing no element of will.

${ }^{5}$ Working on modal logic, von Wright (1951: 2) exhibits the similarities between different modes in the following way: alethic modes: epistemic modes: deontic modes: $\quad$ existential modes:

modes of truth modes of knowing modes of obligation modes of existence

necessary verified obligatory universal

possible ---- permitted existing

contingent undecided indifferent ------

impossible falsified forbidden empty

${ }^{6}$ Comrie (1976: 8) puts the difference between tense and aspect in the following way: "However, although both aspect and tense are concerned with time, they are concerned with time in very different ways. As noted above, tense is a deictic category, i.e. locates situations in time, usually with reference to the present moment, though also with reference to other situations. Aspect is not concerned with relating the time of the situation to any other time-point, but rather with the internal temporal constituency of the one situation; one could state the difference as one between situation-internal time (aspect) and situation-external time (tense).”

${ }^{7}$ In the present study no attempt has been made to compare the Hindi mood system with that of Urdu; however, given the similarities found between these two languages at almost all grammatical levels, it is presumed that both of them show the same modality system.

${ }^{8}$ We are using the term aspect in this paper in a very loose sense in that, for the sake of brevity, a detailed analysis of aspect is not sought, as our aim in this paper is not to establish a full morphological picture of the Hindi tense-aspect system, but rather to investigate some logical aspects within the Hindi mood system only. Thus, questions such as whether in Hindi a telic-atelic aspectual distinction is pertinent or not, whether the progressive is an aspect or not, whether the Hindi future tense can be considered a tense-aspect category or not and whether perfective aspect is only one category (perfective participle only) or two or more (perfective participle plus one or two second members of a compound verb) are not discussed in detail.

${ }^{9}$ Throughout the paper, the following symbols and abbreviations are used:

Symbols: $\square=$ necessarily, obligatorily, $\diamond=$ possibly, $\mathrm{K}=$ knowledge, $\mathrm{K}_{\mathrm{s}}=$ the speaker knows, $\mathrm{B}=$ belief, $\mathrm{B}_{\mathrm{s}}=$ the speaker believes, $\mathrm{W}=$ element of will or desire, $\mathrm{W}_{\mathrm{s}}=$ speaker wants $/$ desires, $\mathrm{W}_{\mathrm{pm} \text {. }}=$ the person referred to in the matrix wants/ desires, . = that, $\mathrm{p}=$ proposition, $\mathrm{t}_{\mathrm{n}-1}=$ prior to the time of utterance, $\mathrm{t}_{\mathrm{n}}=$ concomitantly at the time of utterance, $\mathrm{t}_{\mathrm{n}+1}=$ later than the time of utterance, $\longrightarrow \bullet-\bullet \rightarrow=$ habitual aspect, $\longrightarrow-\longrightarrow=$ continuous aspect, $\longrightarrow \longrightarrow \#=$ perfective aspect, * before a sentence = grammatically unacceptable, ? before a sentence = pragmatically unacceptable; Abbreviations: acc $=$ accusative, dat $=$ dative, erg $=$ ergative, fut $=$ future, ind $=$ indicative, inf $=$ infinitive, $\mathrm{NEG}=$ negation marker, $\mathrm{p}=$ proposition, perfv = perfective, pres = present, sub = subjunctive, ynq = yes-no-question . ${ }^{10}$ For the sake of simplicity, we are introducing the '?' symbol as a conjunction in our formalism, though it is not used between modal operators in any traditional logical theory. Therefore, $\mathrm{K}_{\mathrm{s}} . \square p$ should read like this: 'for all the speaker knows, it is necessarily the case that $p^{\prime}$.

${ }^{11}$ The term optative is used very loosely in this paper. It was originally used in Greek to indicate a mood category which expresses the speaker's desire, hope or wish and therefore should be treated in the section on deontic modality rather than under epistemic modality. But, for the sake of brevity, we are not making a separate section on it. Thus, May they get home safely! (deontic possibility) and They may get home safely (epistemic possibility) are treated in the same manner as our aim is to show that the subjunctive verb form is chiefly used to express modal possibility - whether epistemic or deontic - rather than a modal necessity.

${ }^{12}$ To express the speaker's deontic modality, Hindi has, in addition to the imperatives, some further syntactic constructions as well as other lexical items. A detailed discussion of the Hindi imperatives and other constructions expressing the agent's obligations can be found in Sharma 1999 and 2000 respectively.

${ }^{13}$ Whether an imperative utterance can be assigned truth-values or not is a very difficult question to answer. We have discussed elsewhere (Sharma, 1999) that it is wrong to define imperatives in terms of truth-conditions since they contain 
no truth-conditions whatsoever. Some scholars suggest that a model-theoretic account (in a referentially based theory of meaning) is still possible. So we can think of imperatives in the following terms:

$\begin{array}{ll}\text { indicatives } & \text { truth-conditions } \\ \text { interrogatives } & \text { answerhood-conditions } \\ \text { imperatives } & \text { satisfiability-conditions }\end{array}$

But, satisfiability of what? Of the command issued by the speaker or of the addressee's compliance? In both cases, no clue to the truth-conditions can be found. So, it is wrong to represent an imperative with the schemata which contains a $p$ $(\square ! p)$ in that an imperative has no proposition. We, nevertheless, will not look for any other formalism and make use of $p$ in our formalism. In such cases, $p$ does not stand for a proposition, but rather for an action $x$.

14 'But modality, as will be seen, does not relate semantically to the verb alone or primarily, but to the whole sentence.' Palmer, 1986, pg. 2.

${ }^{15}$ See, inter alia, Hornstein 1990, p. 117.

${ }^{16}$ As noted above, it is difficult to make a clear-cut distinction between tense-aspect elements and modality elements in the Hindi verbal predicate. The necessity and possibility operators in a sentence, for example, are related to all the information contained in the proposition rather than solely to a time-reference-less proposition. In other words, to assert that such and such events necessarily took place or states of affairs obligatorily existed means also that they necessarily took place or existed at a particular point in time in relation to the time of utterance $t_{n}$.

${ }^{17}$ In this group Hooper (1975) classifies the following English verbs: find out, discover, know, learn, note, notice, observe, perceive, realize, recall, remember, reveal and see.

${ }^{18}$ Hooper (1975) puts the following verbs in this category: regret, resent, forget, amuse, suffice, bother, make sense, care, be odd, be strange, be interesting, be relevant, be sorry, be exciting.

${ }^{19}$ According to Hooper (1975), this category of English verbs has two sub-categories, namely, (1) weak assertive nonfactive (think, believe, suppose, expect, imagine, guess, seem, appear, figure, (2) strong assertive non-factive (acknowledge, admit, affirm, allege, answer, argue, assert, assure, certify, charge, claim, contend, declare, divulge, emphasize, explain, grant, guarantee, hint, hypothesize, imply, indicate, insist, intimate, maintain, mention, point out, predict, prophesy, postulate, remark, report, say, state, suggest, swear, testify, theorize, verify, vow, write; agree, be afraid, be certain, be sure, be clear, be obvious, be evident, calculate, decide, deduce, estimate, hope, presume, surmise, suspect.

${ }^{20}$ Hooper (1975) classifies the following English verbs in this category: be likely, be possible, be probable, be conceivable, be unlikely, be impossible, be improbable, be inconceivable, doubt, deny.

${ }^{21}$ There are many other devices to link a matrix verb to its subordinate clause which require a subjunctive mood in the verbal predicate:

yah zarūrī hai ki/ nẫ̄ hai ki ... (It is necessary/ not necessary that...); yah mumkin hai/ nah̃ hai ki ... (It is possible/ not possible that ...); yah asambhav hai/ na $\tilde{\bar{\imath}}$ hai ki ... (It is impossible/ not impossible that ...); ho saktā hai ki (It may

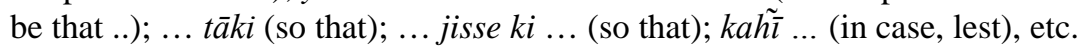

${ }^{22}$ See, for example, Sharma, 1999.

${ }^{23}$ Although, in standard modern Hindi negative necessity and negative possibility are expressed by nah⿱亠䒑 and na respectively, some varieties of Hindi, especially western Hindi, allow na to be replaced by nah̃̄ in almost all the cases of negative possibility. However, nah⿱亠䒑 cannot be replaced by na where it expresses negative necessity. 